\title{
The impact of corporate characteristics on environmental information disclosure: an empirical study on the listed firms in Egypt
}

\author{
Yousra N. Elshabasy \\ Arab Academy for science and technology, AASTCMT, Egypt \\ Finance and Accounting Department
}

\begin{abstract}
Key words
Corporate Characteristics, Corporate Social Responsibility, Environmental Information Disclosure, Egyptian Stock Exchange
\end{abstract}

\begin{abstract}
Companies with good Reputations not only depend on financial results but also on their contribution in environment and social responsibility and sustained growth. This is what the researchers are trying to prove over the past 30 years but still there is no consensus on the validity of this statement, therefore it became one of the debatable areas whether the Corporate Social Responsibility (CSR) can affect the organization financially or economically. Environmental information disclosure (EID) has become an important part in the process of the annual report, the social responsibility report and other information disclosure. This paper aims to assess the impact of several Corporate Characteristics on environmental information disclosure of the listed firms in a developing country. It selects the 50 most active firms in the Egyptian stock exchange and the analysis is done using the financial statements from the disclosure book for the period 2007-2011, prior the revolution, along with the firms' annual reports. The final count for the firms is 45, after excluding banks and insurance companies, for having different disclosure requirements and different corporate governance code. The tests for this research are done using the multiple regression model applied using the SPSS. Findings found that there is an insignificant relationship between two factors of firms' characteristics (Firm Size and Firm Financial Leverage) and EID, while Firm's age showed a negative significant relationship with EID and finally Firm's Profitability showed a positive significant relationship with EID.
\end{abstract}

Corresponding author: Yousra N. Elshabasy

Email addresses for corresponding author: yousraelshabasy@aast.edu

First submission received: 28th May 2017

Revised submission received: 31st July 2017

Accepted: 10th August 2017

\section{Introduction}

Countries try to develop by resorting to several technological techniques and methodologies that eventually might lead to the deterioration of the environment and polluting the climate leading to several natural problems. These nature changes set the alarm for different parties in the society in order for the corporations to show some concern with regard to the environment. It became an obligation on the firms to disclose their responsibility toward the society and the environment and since then environmental information disclosure has become an important part of the accounting information system (Iwata \& Okada, 2011), (Pahuja, 2009) and (Ahmad \& Mousa, 2010).

During the last twenty years, corporate social and environmental reporting became a point of interest for researchers. Environmental disclosure is one of the problems in the corporate environmental argument. Shareholders, the suppliers of foreign capital, the government, employees, customers and the general public, all claim a right to environmental information. Corporate environmental disclosure is a part of social reporting and the environmental disclosures are mainly non-financial in nature (Belal,1999).

In recent years, Environmental information disclosure (EID) became a rising topic with the existence of an increasingly severe deterioration of the ecological environment, therefore environmental protection pressures from government, society and media, and stakeholders have progressively paid much attention to EID of the listed firms (Chang, 2011). Environmental information disclosure (EID) has 
become an important part in the process of annual report, the social responsibility report and other information disclosure (Clarkson et al., 2008).

Academic research is heavily concerned with the area of environmental disclosure and the idea of corporate social responsibility as a broader aspect. Prior literature investigates the concept of social responsibility and the importance of disclosure. However, there isn't much empirical evidence on the environmental disclosure practices taking place in the developing countries (Saha \& Akter, 2013) and (Uwuigbe, 2012) and very limited research is done to investigate the impact of corporate characteristics (Independent Variables) on Environmental Information Disclosure (Dependent variable) in the developing nations. Therefore, this research attempts to study this relation in some listed Egyptian firms, focusing on four main types of corporate characteristics which are firm size, firm age, firm leverage and firm's profitability.

The next section of this research shows the literature and the research hypotheses; section 3 presents the methodology, section 4 presents findings followed by the conclusion, finally section 6 provides the limitations along with few recommendations.

\section{Literature Review}

"Transparency via information disclosure is increasingly at the heart of a number of global environmental governance initiatives" cited by (Gupta, 2008). The requirements of environmental standards, issued by International Organization for Standardization (ISO) have been the basis to several researches on environmental responsibility. It is argued by (Neyland, 2007) that environmental information disclosure gives more transparency to the annual report.

Theories prove that social and environmental disclosure affects the corporations' economic, financial, environmental and social performances (Gray, 2006), hence it is thought that sustainability reporting may improve corporate behavior. Few theories are to be introduced; the first one would be the stakeholders' theory, according to (Roberts, 1992) the society is divided into subgroups, each affecting the firms differently but they all share a common nature which is the concern about the firm's responsibility towards the environment, it is added that information disclosure is the language between firms and stakeholders. Stakeholder theory is considered a broader view for the agency theory that states that there is an agency relationship between the principal (shareholders) and the agent (management) and that the agent should work for the interest of the principal to avoid any conflict of interest which leads to the agency problem, (Jensen \& Meckling, 1976).

Moving to a further broader view, comes the legitimacy theory which takes the society as a whole and explains its effect on the firms' disclosure intensity (Cho \& Patten, 2007).This theory focuses on the social contract that should exist between the corporations and the society, this contracts states that there should be a link between the values of the corporation and the values of the society, if the firm couldn't satisfy the society then the contract is considered broken and thus the firms are negatively impacted and therefore to avoid this dilemma, firms try to enhance their environmental disclosure process (Milne \& Patten, 2002), (Deegan, 2002) and (Patten,1992).

A third theory that enhances the importance of the previously mentioned theories is the Voluntary disclosure theory which focuses on the amount of information to be disclosed and not only the type of information, as explained by (Clarkson et al., 2008). Brammer \& Pavelin (2006) state that information asymmetry problem is reduced between the firm and the stakeholders through the efforts made by the firms to disclose as much information reflecting good environmental performance. Corporate characteristics can determine the quality of the information disclosed and every corporation has different characteristics that might have an impact on the disclosure process (Lang \& Lundholm, 1993).

\subsection{Firm Size and Environmental Information Disclosure}

Previous literature has explained different relations between firm size and Environmental Information Disclosure. The majority of the research showed a positive relation between the two variables such as the research conducted by (Hartikayanti et al., 2016), (Andrikopoulos \& Kriklani, 2013), (Michelon \& Parbonetti, 2012) and (Montero et al., 2011). The main reason behind this positive relation is the idea of how visible the firm is to the society, so the larger the firm is, the more visible it becomes and therefore it is obligated to disclose more information (Patten, 2002) and (Cormier \& Gordon, 2001). Other reason 
stated by (Despina et al., 2011), is that larger firms care about their reputation and, so they try to increase their financial performance through disclosing more environmental information to gain the public trust.

Other researches find that the firm size has no effect on the level of environmental information disclosure like the study conducted by (Ebiringa et al., 2013) and (Veronica, 2009). A negative relation is not proven in studies concerning developing countries.

\subsection{Firm Age and Environmental Information Disclosure}

Age could actually help firms become more efficient. Over time, firms discover what they are good at and learn how to do things better (Arrow, 1962), (Jovanovic \& Hart, 1982) and (Ericson \& Pakes, 1995). They specialize and find ways to standardize, coordinate, and speed up their production processes, as well as to reduce costs and improve quality. A positive relation is suggested by prior literature explaining that if the firm has been established since a long time ago this shows that the firm is satisfying its stakeholders as it meets its financial and social/environmental obligations, this is mentioned in the research conducted by (Liu \& Anbumozhi, 2009) and (Choi, 1999). A motive to meet these obligations could be to protect its reputation by being involved in the environmental information disclosure process (Roberts, 1992).

\subsection{Firm Leverage and Environmental Information Disclosure}

Agency theory argues that firm leverage is determined by agency costs, which results from potential conflicts of interests, leading managers to adopt leverage choices that improve their own private benefits rather than maximize shareholders wealth (Gray et al., 1995). Financial leverage is a very important corporate characteristic therefore many arguments exist showing different relations. Starting with studies proving a positive relation comes those of (Andrikopoulos \& Kriklani,2013) and (Clarkson et al., 2011) and the reason is because of the stockholders monitoring demand that increases when the level of firm's leverage increases leading firms to increase the level of disclosure. Ho \& Taylor (2007), prove a positive relation by stating that this reduces the agency cost/ agency problem.

On the other hand, (Sembiring, 2005) explains the existence of a negative relation by stating that the firms do not want to be of point of concentration by the creditors. Nur (2012) supported this negative relation. Other reason mentioned in old literature by (Belkaoui \& Philip, 1989) is that companies tend to lower all kinds of costs in order to increase their profits to satisfy some credit agreements. Finally, there are researches that say there is no relation between leverage and the environmental information disclosure such as (Permana \& Raharja, 2012) and (Veronica, 2009).

\subsection{Firm profitability and Environmental Information Disclosure}

Profitability is defined as an indicator to the firm's performance in managing its assets (Juhmani, 2014). Based on the agency theory, profitability is considered an indicator for satisfying the shareholders' needs, especially when ROE is used as profitability measurement as it measures the firm's performance (Ebrahim et al., 2015). Positive and negative relations as well as no relation exists between the firm profitability and Environmental Information Disclosure, however the majority of prior literature explains the positive relation. Prior literature stating a negative relation (Huang \& Kung, 2010) and (Kathyayini et al., 2012) while literature stating no relation includes (Zeng et al., 2012), (Cho et al., 2010) and (Ahmad et al., 2003).

Explanations for a positive relation focuses on two main points, first is that firms with high profitability try to increase their public image as well as attracting new investors therefore they tend to increase the level of environmental disclosure (De Villiers \& Van Staden, 2011). Second, firms with high profits have better ability to pay for the costs of the environmental disclosure (Brammer \& Pavelin, 2008). Based on previous studies and results, it can be seen that large sized firms, firm's age, firm financial leverage level, and firm's profitability can have significant effect on Environmental Information Disclosure; therefore, the research hypotheses are stated as follows:

- H1: There is a significant relationship between Firm size and Environmental Information Disclosure

- H2: There is a significant relationship between Firm Age and Environmental Information Disclosure 
- H3: There is a significant relationship between Firm Financial Leverage and Environmental Information Disclosure

- H4: There is a significant relationship between Firm Profitability and Environmental Information Disclosure

\section{Research Methodology}

Statistical techniques and tools are applied to test the significance of the research hypotheses using theoretical and quantifiable data from the Disclosure book, annual reports and some data were purchased from the Egyptian Company for Information Dissemination (EGID). The statistical tools used are descriptive statistics, correlation analysis and regression analysis. Data is tested from the year 2007 until 2011 which is before the revolution, and the population used in this research is the Egyptian stock exchange (EGX), taking a sample of the 50 most active firms. In this investigation the ordinary least squares (OLS) method of regression was applied in executing the analysis, (Cohen et al., 2007).

\subsection{Dependent Variable}

In this study the dependent variable is the environmental information disclosure (EID), Environmental information (EI) must help the society and companies to recognize the impact of business decisions on the environment (Milne \& Patten, 2002), (Kuk et al., 2005). One of the techniques is using measures that quantify the level of environmental disclosure (Milne \& Adler, 1999), this could be done by counting the number of pages, sentences and words, amount of news including their types (bad, good, or neutral news) or the number of disclosure items. However, this technique has few disadvantages, such as not taking into account the use of non-textual information (McMurtrie, 2005) as well as the inability to assess the quality of the disclosed information (Patten, 2002).

The second technique is a scoring measure where the text is classified. By using this measurement tool, researchers quantify the provided environmental information by identifying specific environmental items, and then they analyze the disclosure on each item using a yes/no $(1,0)$ scoring. At the end, a score per firm can be calculated, this is based on (Al-Tuwaijri et al., 2004) and (Clarkson et al., 2008).

Several indexes are established to support the second technique, for instance (Clarkson et al., 2008) developed a content analysis index, based on the Global Report Initiative (GRI) reporting guidelines to assess the level of discretionary Environmental Disclosure (ED) in environmental and social responsibility reports. Another index measures the extent of information based on the firms' annual report by using a quantitative component as it applies a scoring system giving zero point in the absence of the item and one point in the item presence (Harris et al., 2005) and (Greene, 2012).

This research uses an index that suits the Egyptian firms which is appendix A, the index is suggested by (Carreira et al., 2014) and (Juhmani, 2014) containing a total number of 26 items, from Annual Report (16 items) and from Annex (10 items), which are other attachments to the annual report, by assigning a score of 1 if a firm discloses an item and a score of 0 if it does not. For each firm, a disclosure index was computed as the ratio of the actual score given to the firm divided by the total score.

\subsection{Independent Variable}

Table (1) shows the measuring tools that this research uses based on the prior mentioned literature and these are the most commonly used measurements.

Table (1): Independent Variables Measurements

\begin{tabular}{|l|l|l|}
\hline Variables & Measurement & Reference \\
\hline $\begin{array}{l}\text { Firm size } \\
\text { (FSIZE) }\end{array}$ & Natural log of total assets & (Barako et al., 2006) and (Lim et al., 2007) \\
\hline $\begin{array}{l}\text { Firm Age } \\
\text { (FAGE) }\end{array}$ & $\begin{array}{l}\text { Log of the number of years since the } \\
\text { firm's foundation }\end{array}$ & $\begin{array}{l}\text { (Arrow, 196 2), (Mueller, 1972), (Ericson \& Pakes, } \\
\text { 1995) and (Soliman, 2013) }\end{array}$ \\
\hline $\begin{array}{l}\text { Firm Leverage } \\
\text { (FLEV) }\end{array}$ & $\begin{array}{l}\text { Total Debt divided by the Total } \\
\text { Assets of the firm. }\end{array}$ & $\begin{array}{l}\text { (Chen, 2003), (Baharuddin et al., 2011) and } \\
\text { (Buferna et al.,2005) }\end{array}$ \\
\hline $\begin{array}{l}\text { Firm Profitability } \\
(\text { PROF) }\end{array}$ & Net income/total equity & (Julius, 2016) and (Juhmani, 2014) \\
\hline
\end{tabular}




\subsection{Research Model}

This research uses a multiple regression model to examine and test for the impact of multiple independent variables, which are the corporate characteristics, on the dependent variable, which is the environmental information disclosure, of the most active firms listed in the Egyptian stock exchange

$\mathrm{EID}=\beta 0+\beta 1 \mathrm{FSIZE}+\beta 2 \mathrm{FAGE}+\beta 3 \mathrm{FLEV}+\beta 4 \mathrm{FPROF}+\varepsilon$

Where: EID: is environmental information disclosure, FSIZE: is Firm size, FAGE: is Firm age, FLEV: is Firm Financial Leverage, FPROF: is the firm's profitability, $\beta$ : represents the regression coefficient, $\varepsilon$ : represents the error term.

\section{Findings and Discussion}

Using SPSS, testing the hypotheses includes descriptive statistics followed by correlation analysis and then the regression analysis.

\subsection{Descriptive Statistics}

The aim of this analysis is to describe the variables by showing the mean, minimum and maximum values and the standard deviation of the dependent and independent variables

\begin{tabular}{|l|l|l|l|l|l|}
\hline & $\mathrm{N}$ & Minimum & Maximum & Mean & Std. Deviation \\
\hline EID & 225 & .00 & .88 & .2174 & .22652 \\
\hline FSIZE & 225 & 17.447634 & 25.276637 & 21.109474 & 1.689402 \\
\hline FAGE & 225 & 14 & 37 & 23.96668 & 5.899404 \\
\hline FLEV & 225 & .000000 & .998675 & .20985174 & .208265971 \\
\hline FPROF & 225 & -29.0000 & 104.0000 & 14.947059 & 18.2105062 \\
\hline
\end{tabular}

Table (2): Descriptive Statistics

The table indicates that the environmental information disclosure in the sample companies is $22 \%$ showing a low level of disclosure by the Egyptian firms. That isn't consistent with (Akbas \& Canikli, 2014) in Turkish (93.55\%), (Suttipon \& standton, 2012) in Thailand (96\%) and (Juhmani, 2014) in Bahrain (37\%). It's also shown in the table that environmental disclosure score level has a minimum of $0 \%$ and a maximum of $88 \%$. The low percentage of environmental information disclosure in annual reports could be referred to the fact that this type of information is voluntary in nature, and no efficient rules or regulations enforce companies to reveal it. While the maximum level by which Egyptian firms reveal their information reached $88 \%$

Regarding the independent variables, Table (2) shows that the firm sizes have an average of $21 \%$ with a min of $17 \%$ and a max of $25 \%$. It also shows an average firm age of 1.4324 years, a min of 14 and a max of 37. The leverage ratio in the Egyptian firms indicated an average level of is $20.89 \%$ and it tends to range between a minimum of $0 \%$ and a maximum of $99.86 \%$, with a standard deviation of $20.82 \%$. The last independent variable, which is the profitability level for Egyptian listed firms, tends to have an average of $14.95 \%$, with extreme min and max levels as well as standard deviation.

\subsection{Correlation Analysis}

To assess for the correlation between the variables and determine whether there is a multicollinearity problem in the research model or not, the Pearson's Correlation Coefficient is employed. Table (3) shows the direction and strengths of the relationships between all variables with one another. According to (Bryman \& Cramer, 1997), Pearson's correlation between the independent variables is not reflected as a problem unless it is higher than 0.80 , because independent variables with coefficients greater than 0.80 are supposed of showing a multicollinearity. However, as long as the highest correlation in table (3) is still less than 0.80 , so this confirms that there is no multicollinearity between the independent variables used in the research model.

\begin{tabular}{|l|l|l|l|l|l|}
\hline & EID & FLEV & FSIZE & FAGE & FPROF \\
\hline EID & 1 & & & & \\
\hline FLEV & $.220^{* *}$ & 1 & & & \\
\hline FSIZE & .117 & $.261^{* *}$ & 1 & & \\
\hline FAGE & $-.200^{* *}$ & -.079 & $-.346^{* *}$ & 1 & \\
\hline FPROF & $.281^{* *}$ & .123 & $.198^{* *}$ & $-.189^{* *}$ & 1 \\
\hline
\end{tabular}

Table (3): Correlation Analysis 


\subsection{Regression Analysis}

Regression analysis is a more powerful tool than the correlation analysis as it doesn't only explain the trend and strength of a relationship, but shows the casual effect of this relationship. The multiple regression equation, stated previously, is analyzed with the ordinary least squared method (OLS) using the Statistical Package for Social Science (SPSS) program.

As long as the hypotheses formulated to analyze this relationship are declared without a particular direction, then the correlation and regression must be two-tailed as stated by (Ho, 2006). The regression analysis of the environmental disclosure of Egyptian firms shows that the significance of the model is 0.000 , which indicates that it's highly significant, as long as it's far below 0.05 .

\begin{tabular}{|l|l|l|}
\hline Model & Sig. \\
\hline 1 & Regression & $.000^{\mathrm{b}}$ \\
\hline
\end{tabular}

Table (4): ANOVA Model

\begin{tabular}{|c|c|c|c|c|c|c|}
\hline \multicolumn{7}{|c|}{ EID $=\beta 0+\beta 1$ FSIZE $+\beta 2$ FAGE $+\beta 3$ FLEV $+\beta 4$ FPROF $+\varepsilon$} \\
\hline & & \multicolumn{2}{|c|}{ Unstandardized Coefficients } & Standardized Coefficients & \multirow[b]{2}{*}{$t$} & \multirow[b]{2}{*}{ sig } \\
\hline & & B & Std. Error & Beta & & \\
\hline \multirow{5}{*}{1} & (Constant) & .581 & 300 & & 1.938 & .054 \\
\hline & FSIZE & -.003 & .009 & -.025 & -.362 & .717 \\
\hline & FAGE & -.267 & .122 & -.148 & -2.196 & $.029^{* *}$ \\
\hline & FLEV & .049 & .168 & .045 & .292 & .771 \\
\hline & FPROF & .003 & .001 & .237 & 3.626 & $.000^{* * *}$ \\
\hline
\end{tabular}

Table (5): Regression Results

Data in the above table show that, a sig level of 0.717 , greater than 0.05 , for the firm's size indicates an insignificant relationship with environmental information disclosure of Egyptian firms, this result rejects the hypothesis of a significant relationship between the two variables in the Egyptian firms. Second, the firm age shows a significance level of 0.029 indicating the existence of a significant relation which is negative, and this makes the second research hypothesis acceptable. Moving the third hypothesis which is firm financial leverage, a significance level of 0.771 , which is greater than 0.1, indicates an insignificant relationship between the firm financial leverage and environmental information disclosure, this result rejects the hypothesis of a significant relationship between the two variables in the Egyptian firms. Finally, the fourth variable that has an accepted hypothesis as well is the firm profitability that has a significance level of 0.000 showing a positive relation as well.

\section{Conclusion}

Many pressures cause the firms to disclose environmental information in the annual report, and these pressures come from different parties in the society like the stakeholders, the government and other forces surrounding the firm. Also, the fear of losing your public image and the urge to increase the firm's performance gives the firm a greater motive to disclose environmental information, this was suggested by (Suttipon \& standton, 2012).

This research objective is to observe the effect of some variables on the environmental disclosure by Egyptian firms. Thus, for the purpose of this research, the impact of four independent variables which are firm size, firm age, firm leverage and firm profitability are analyzed in the research model. The research model is designed to measure the effect of these variables on the environmental disclosure of the 50 most active firms listed in the EGX from the period 2007-2011.

The findings of this study lead to the acceptance of two hypotheses which state that there is a significant relation between two independent variables which are firm age and firm profitability and the dependent variable which is environmental information disclosure, while the other two hypotheses are rejected referring to an insignificant relationship.

\section{Research limitations and direction for further research}

Research limitations exist in almost all researches and this is what makes research alive as to always try to solve the limitations. One of the limitations faced during this study is the use of the disclosure book as the last one was issued in 2011 so the sample of this research stopped at year 2011. Also, some data was not found as the most active firms are not constant because of the entering and 
exiting of some firms from a year to another, though this was solved by using another data source which is the Egyptian Company for Information Dissemination (EGID).

Another Limitation is that there is no availability of previous research regarding this area of study especially in a developing country such as Egypt. Finally, the sample size used in this study is 45 firms and for a five-year study period. So, simplifying the results for all firms becomes limited due to the nature of the empirical model used and also the study is conducted only in Egypt due to inability to access data in other countries. And most of the Egyptian firms did not disclose information regarding the environment so this limited this study to include many firms in the analysis.

The corporate environmental disclosure is considered a sign of transparency or credibility for firms, which in turn helps in attracting new investors. Hence, a very minor change in a company's environmental disclosure level may affect the level of investments on the company's shares, and therefore, firms have to pay attention to their environmental disclosure level and give it some worthy considerations and concern. Therefore, as a direction for further research, other independent variables could be added to test their impact on the environmental information disclosure like adding the corporate governance factors as well as another research direction which is micro and macroeconomic factors.

\section{References}

Ahmad, Z., Hassan, S., \& Mohammad, J. (2003). Determinants of Environmental Reporting in Malaysia, International Journal of Business Studies, 11(1), 69-90.

Ahmed, N. \& Mousa, F. (2010). Corporate environmental disclosure in Libya: A little improvement, World Journal of Entrepreneurship, Management and Sustainable Development, 6(1-2), 149-159.

Akbas, H. \& Canikli, S. (2014). Corporate Environmental Disclosures in a Developing Country: An Investigation on Turkish Listed Companies, 6(2), 50-57.

Al-Tuwaijri, S., Christensen, T. \& Hughes II, K. (2004). The Relations among Environmental Disclosure, Environmental Performance, and Economic Performance: A Simultaneous Equations Approach. Accounting, Organizations and Society, 29(4-5), 447-471.

Andrikopoulos, A. \& Kriklani, N. (2013). Environmental disclosure and financial characteristics of the firm: the case of Denmark, Corporate Social Responsibility and Environmental Management, 20(1), 55-64.

Arrow, K. (1962). The economic implications of learning by doing. American Economic Review, 29(3), 155173.

Baharuddin, N., Khamis, Z., Mansor, W., Mahmoud, W. \& Dollah, H. (2011). Determinants of capital structure for listed construction companies in Malaysia, Journal of Applied Finance \& Banking, 1(2), $115-132$.

Barako, D., Hancock, P. \& Izan, H. (2006). Factors Influencing Voluntary Corporate Disclosure by Kenyan Companies, Corporate Governance: An International Review, 14(2), 107-125.

Belal, A. (1999). Corporate Social Disclosure in Bangladesh Annual Reports. The Bangladesh Accountants, ICAB, 27(1), 76-81.

Belkaoui, A. \& Philip G. (1989). Determinants of the Corporate Decision to Disclose Social Information. Accounting, Auditing and Accountability Journal, 2(1), 36- 51.

Brammer, S. \& Pavelin, S. (2008). Factors Influencing the Quality of Corporate Environmental Disclosure, Business Strategy and the Environment 17(2), 120-136.

Brammer, S., \& Pavelin, S. (2006). Voluntary environmental disclosures by large UK companies. Journal of Business Finance \& Accounting, 33(7-8), 1168-1188.

Bryman, A. \& Cramer, D. (1997). Quantitative Data Analysis with SPSS for Windows: A Guide for Social Scientists, $2^{\text {nd }}$, ed., Routledge.

Buferna, F., Bangassa, K. \& Hodgkinson, L. (2005). Determinants of Capital Structure: Evidence from Libya, Research Paper Series 8, University of Liverpool.

Carreira F., Damião A., Abreu R. \& David F. (2014). Environmental Disclosure from the Accounting to the Report Perspective. In Proceedings of the 16th International Conference on Enterprise Information Systems, working paper, 3, 496-501. 
Chang, k. (2011). The Effects of Ownership and Capital Structure on Environmental Information Disclosure: Empirical Evidence from Chinese Listed Electric Firms. School of Finance, 2(12), 637649.

Chen, J. (2003). Determinants of capital structure of Chinese-listed companies. Journal of Business Research, 57(12), 1341-51.

Cho, C. \& Patten, D. (2007). The role of environmental disclosures as tools of legitimacy: A research note. Accounting, Organizations and Society, 32(7), 639-647.

Cho, C., Roberts, R. \& Patten, D. (2010). The language of US corporate environmental disclosure. Accounting, Organizations and Society, 35(4), 431-443.

Choi, J. (1999). An investigation of the initial voluntary environmental disclosures made in Korean semiannual financial reports. Pacific Accounting Review, 11(1), 73-102.

Clarkson, P., Overell, M. \& Chapple, L. (2011). Environmental reporting and its relation to corporate environmental performance. Abacus, 4(1), 27-60.

Clarkson, P., Richardson, G. \& Vasvari, F. (2008). Revisiting the relation between environmental performance and environmental disclosure: an empirical analysis. Accounting, Organizations and Society, 33(4-5), 303-327.

Cohen, L., Manion L., \& Morrison K. (2007). Research methods in education. Routledge, 0-203-02905-4.

Cormier, D. \& Gordon, I. (2001). An examination of social and environmental reporting strategies. Accounting, Auditing - Accountability Journal, 14(5), 587-617.

De Villiers, C. \& van Staden, C. (2011). Where firms choose to disclose voluntary environmental information. Journal of Accounting and Public Policy, 30(6), 504-525.

Deegan, C. (2002). Introduction: the legitimizing effect of social and environmental disclosures - a theoretical foundation. Accounting, Auditing \& Accountability Journal, 15(3), 282-311.

Despina, G., Efthymios, G. \& Antonios, S. (2011). The Relation between Firm Size and Environmental Disclosure. International Conference on Applied Economics - ICOAE 2011, 179-186.

Ebiringa, O., Emeh, Y. \& Obi, J. (2013). Effect of Firm Size and Profitability on Corporate Social Disclosures: The Nigerian Oil and Gas sector in Focus. British Journal of Economics, Management \& Trade, 3(4), 563-574.

Ebrahim, M., Soliman, S. \& Rezk, A. (2015). Influence of Firm Size and Profitability on Corporate Social Responsibility Disclosures by Banking Firms (CSRD): Evidence from Jordan. Journal of Applied Finance \& Banking, 5(6), 97-111.

Ericson R., \& Pakes A., (1995). Markov-perfect industry dynamics: a framework for empirical work. The Review of economic studies, 62(1), 53-82.

Gray, R. (2006). Does Sustainability Reporting Improve Corporate Behaviour? Wrong Question? Right Time? Accounting and Business Research, 36(1), 65-88.

Gray, R., Kouhy, R., \& Lavers, S. (1995). Corporate social and environmental reporting: a review of the literature and a longitudinal study of UK disclosure. Accounting, Auditing \& Accountability Journal, 8(2), 47-77.

Greene, W. (2012). Econometric Analysis. London: Prentice Hall Inc. 7th Edition.

Gupta, A. (2008). Global environmental politics, Transparency under Scrutiny: Information Disclosure in Global Environmental Governance, 8(2), 1-7.

Harris, L., Scaramozzino, P., \& Fattouh, B. (2005). Capital structure in South Korea: a quantile regression approach. Journal of Development Economics, 76(1), 231- 250.

Hartikayanti, H., Trisyardi, M. \& Saptono B. (2016). Effect of corporate characteristics on environmental disclosure. IJABER, 14(10), 6111-6134.

Ho, L. \& Taylor, M. (2007). An Empirical Analysis of Triple Bottom-Line Reporting and its Determinants: Evidence from the United States and Japan. Journal of International Financial Management Accounting, 18(2), 123-150.

Ho, R. (2006). Handbook of Univariate and Multivariate Data Analysis and Interpretation with SPSS, 3rd, ed., Taylor and Francis Group.

Huang, C. \& Kung, F. (2010). Drivers of environmental disclosure and stakeholder expectation: Evidence from Taiwan. Journal of Business Ethics, 96(3), 435-451. 
Iwata, H. \& Okada K. (2011). How does environmental performance affect financial performance? Evidence from Japanese manufacturing firms. Ecological Economics, 70(9), 1691-1700.

Jensen, M. \& Meckling, W. (1976). The Agency Theory of the Firm: Managerial Behavior, Agency Cost and Ownership Structure. Journal of Financial Economics 3(4), 305-360.

Jovanovic, G. \& Hart, O. (1982). Corporate financial structure and managerial incentives, in McCall, J. (Ed.), The Economics of Information and Uncertainty, University of Chicago press, Chicago, IL.

Juhmani, O. (2014). Determinants of Corporate Social and Environmental Disclosure on Websites: The Case of Bahrain. 2(4), $77-87$.

Julius, O (2016). The Effect of Profitability to the Disclosure of Corporate Social Responsibility on Mining Companies Listed on Indonesian Stock Exchange in the Year 2010-2012. Journal of Business and Management,18(6),69-78

Kathyayini, K., Tilt, C. \& Lester, L. (2012). Corporate governance and environmental reporting: an Australian study. Corporate Governance, 12(2), 143-163.

Kuk, G., Fokeer, S. \& Hung, W. (2005). Strategic Formulation and Communication of Corporate Environmental Policy Statements: UK Firms' Perspective. Business Ethics, 58(4), 375-385.

Lang, M. \& Lundholm, R. (1993). Cross sectional Determinants of Analysts Ratings of Corporate Disclosures. Journal of Accounting Research. 31(2), 246-271.

Lim, S., Matolcsy, Z. \& Chow D. (2007). The Association between Board Composition and Different Types of Voluntary Disclosure. European Accounting Review, 16(3), 555-583.

Liu, X. \& Anbumozhi, V. (2009). Determinant factors of corporate environmental information disclosure: an empirical study of Chinese listed companies. Journal of Cleaner Production, 17(6), 593-600.

McMurtrie, T. (2005). Factors influencing the publication of social performance information: an Australian case study. Corporate social responsibility and environmental management, 12(3), 129-143.

Michelon, G. \& Parbonetti, A. (2012). The effect of corporate governance on sustainability disclosure. Journal of Management - Governance, 16(3), 477-509.

Milne, M. \& Patten, D. (2002). Securing organizational legitimacy. An experimental decision case examining the impact of environmental disclosures. Accounting, Auditing \& Accountability Journal, 15(3), 372-405.

Milne, M. \& Adler, R. (1999). Exploring the reliability of social and environmental disclosures content analysis. Accounting, Auditing \& Accountability Journal, 12(2), 237 - 256.

Montero, M., Perez, P. \& Esteban, C. (2011). Corporate Environmental Disclosure and Legitimacy Theory: A Europe Perspective. Environmental Engineering - Management Journal (EEMJ), 10(12), 18831991.

Mueller D. (1972). A Life Cycle Theory of the Firm. Journal of Industrial Economics, 20(3), 199-219.

Neyland, D. (2007). Achieving Transparency: The Visible, Invisible and Divisible in Academic Accountability Networks, Organization. SAGE, 14(4), 499-516.

Nur, M. (2012). Analisis Faktor-Faktor yang Mempengaruhi Pengungkapan Corporate Social Responsibility di Indonesia: Studi Empiris pada Perusahaan Berkategori High Profile Yang Listing di Bursa Efek Indonesia. Journal Nominal, 1(1), 22-34.

Pahuja, S. (2009). Relationship between environmental disclosures and corporate characteristics: a study of large manufacturing companies in India. Social Responsibility Journal, 5(2), 227-244.

Patten, D. (2002). The relation between environmental performance and environmental disclosure. Accounting, Organizations and Society, 27(8), 763-773.

Patten, D. (1992). Intra-industry environmental disclosures in response to the Alaskan oil spill: a note on legitimacy theory. Accounting, Organizations and Society, 17(5), 471-475.

Permana, V. \& Raharja, A. (2012). Pengaruh kinerja lingkungan dan karakteristik perusahaan terhadap corporate social responsibility (csr) disclosure: Studi Empiris pada Perusahaan Manufaktur yang Terdaftar di BEI. Diponegoro Journal of Accounting, 1(2), 1-12.

Roberts, R. (1992). Determinants of corporate social responsibility disclosure: an application of stakeholder theory. Accounting, Organizations and Society, 17(6), 595-612. 
Saha, A. \& Akter, S. (2013). Relationship between environmental reporting in corporate annual reports and corporate profitability in Bangladesh. Global Conference on Business - Finance Proceedings, $8(1), 75-86$.

Sembiring, E. (2005). Karakteristik Perusahaan Dan Pengungkapan Tanggung Jawab Sosial: Study Empiris Pada Perusahaan Yang Tercatat Di Bursa Efek Jakarta. Simposium Nasional Akuntansi, 8(1), 379-395.

Soliman M. (2013). Firm Characteristics and the Extent of Voluntary Disclosure: The Case of Egypt. Research Journal of Finance and Accounting, 4(17), 71-80.

Suttipun, M., \& Stanton, P. (2012). A study of Environmental Disclosures by Thai listed Companies on Websites. Procedia Economics and Finance, 2(14), 9-15.

Uwuigbe, U. (2012). Web-Based corporate environmental reporting in Nigeria: A study of listed companies. Informatica Economica, 16(3), 27-36.

Veronica, T. (2009). Pengaruh karakteristik perusahaan terhadap pengungkapan tanggungjawab sosial pada perusahaan sektor pertambangan yang terdaftar di bursa efek Indonesia, Fakultas Ekonomi. Universitas Gunadarma, university paper, 1-11.

Zeng, S., Xu, X., Yin, H. \& Tam, C. (2012). Factors that drive Chinese listed companies in voluntary disclosure of environmental information. Journal of Business Ethics, 109(3), 309-321.

\section{Appendix A- Index of Environmental Disclosure}

\begin{tabular}{|l|l|}
\hline \multicolumn{2}{|l|}{ Annual Report (16 items) } \\
\hline 1 & Environmental programs and policies (0-1). \\
\hline 2 & Preventive measures/environmental protection (0-1). \\
\hline 3 & Compliance with environmental regulations (0-1). \\
\hline 4 & Reference to certification (0-1). \\
\hline 5 & Environmental investments/capital expenditures (past and in the current year) (0-1). \\
\hline 6 & Environmental performance/risks and impact on the environment (quantitative information) (0-1). \\
\hline 7 & Environmental indicators (0-1). \\
\hline 8 & Environmental management system (0-1). \\
\hline 10 & Training on the environment (0-1). \\
\hline 11 & External environmental audit (0-1). \\
\hline 12 & Future environmental investment \& expenditures (0-1). \\
\hline 13 & Awards and recognition related to the environment (0-1). \\
\hline 14 & Mention of improvements made year by year (0-1). \\
\hline 15 & Mention of an environmental/sustainability report (0-1). \\
\hline 16 & Initiative, awareness campaign, study, conferences (0-1). \\
\hline
\end{tabular}

\begin{tabular}{|l|l|}
\hline \multicolumn{2}{|l|}{ Annex (10 items) } \\
\hline 1 & Measurement criteria related with the environment (0-1). \\
\hline 2 & Environmental incentives (0-1). \\
\hline 3 & Environmental expenditures allocated to results (expenses: operating costs) (0-1). \\
\hline 4 & Environmental capitalized expenditures (investment) (0-1). \\
\hline 5 & Environmental liabilities (0-1). \\
\hline 6 & Environmental contingent liabilities (0-1). \\
\hline 7 & Environmental provisions (0-1). \\
\hline 8 & Fees/penalties relating to environmental issues (0-1). \\
\hline 9 & Heading: "Information on environmental matters (0-1)." \\
\hline 10 & Heading "CO2 licenses (0-1)." \\
\hline
\end{tabular}

